\title{
The Charms of Nature: Darwin on Meaning and Value
}

\author{
Darwin Loves You: Natural Selection and the Re-enchantment of the World, by \\ George Levine. Princeton: Princeton University Press, 2006. pp. xxiii + 304, s/b \$18.95
}

\author{
Adam M. Goldstein
}

Published online: 22 April 2009

(C) Springer Science + Business Media, LLC 2009

\begin{abstract}
I review George Levine's provocative and highly original book Darwin Loves You. Levine, whose "home discipline" is English Literature, offers a compelling interpretation of Darwin's works, evaluating their content and Darwin's prose style to identify a distinctly Darwinian attitude toward nature as a source of meaning and value. Levine believes that Darwin exemplifies the capacity to feel "enchantment" about the natural world, suggesting that, if Darwin's example were followed, a "Darwinian re-enchantment of the world" would be brought about. This would offer a secular, non-supernatural basis for purpose, meaning, and value. I conclude with a few critical remarks about the scope and cogency of Levine's proposal.
\end{abstract}

Keywords Darwin, Charles • Enchantment • Natural selection - Sexual selection • Value • Argument from design - Problem of evil • Levine, George

\section{Introduction}

George Levine's aim in Darwin Loves You is to argue that Darwin's own understanding of nature can and should serve as a model for a non-supernatural, secular conception of meaning and value. To understand this aim, consider Augustine's vivid account of "concupiscence of the eyes," which serves as a dramatic counterpoint to the account of meaning and value Levine finds in Darwin.

\section{A. M. Goldstein $(\varangle)$}

Department of Philosophy, Iona College,

715 North Avenue, New Rochelle, NY 10801, USA

e-mail: agoldstein@iona.edu
To satisfy [a] morbid craving, monstrous sights are exhibited at shows. From the same motive efforts are made to scrutinize the secrets of the natural world that lie beyond our sight; knowledge of these is of no profit, yet people want to know them simply for the sake of knowing. The same motive prompts some to seek perverted knowledge through magical practices.

..

[T] he many minute, contemptible things that solicit our curiosity each day are beyond counting .... [W] [Wen I am sitting at home, why does a lizard catching flies, or a spider binding them when they blunder into its web, often have me gazing intently? Does the fact that these animals are so small make any difference to the situation? True, I pass from watching them to praising you, wonderful creator and dispenser of all that is, but it is not in that frame of mind that I begin to watch. (Augustine 2001, 213-14)

As will be seen, these passages reflect a view of the significance of the observation of nature which is precisely at odds with what Levine believes to be Darwin's. Augustine finds the close study of nature, particularly in its miniature aspects, to be morally abhorrent and only partially redeemed by the access it provides to divinity; Darwin (on Levine's reading) finds the minute study of nature to be best taken as an end itself and indeed, to be the activity in which the value of life itself is most clearly seen. Levine identifies Darwin as a man who, charmed by what he found in nature-for instance, in his study of barnacles-finds community with every plant and animal, coming to love all living things, and 
coming to feel what his place in the universe is: Quite literally, Levine suggests, Darwin loves you, just as he loves every other living thing.

Darwin Loves You begins, in chapter one, with an account of what Levine (p. 1), borrowing from Max Weber, calls "the disenchantment of the world:" As science progresses, providing rational explanations for more and more of what was once regarded as mysterious and sacred, the world seems, as a result, to become less appealing a place to live, more and more absent of meaning. This problem sets up the central task of the book, which is to elaborate a non-supernatural account of life's value. The rest of the book follows a two-part plan. First, Levine works to establish the motivation and theoretical foundation for the work (chapters 2-4); second, he advances his novel readings of Darwin (chapters 5-7), offering a Darwinian solution to the problem of the disenchantment of the world. This amounts to explaining the sense in which "Darwin loves you" should be understood. This second part of the book, in which Levine answers to his calling as a scholar of literature-assessing texts in view of their language and meaning - is by far the more interesting, important, and better executed. Moreover, the essential points of its content most likely to be of interest to readers of Evolution: Education \& Outreach are independent of the work of the first part. Accordingly, I will not provide any detailed or systematic account of this first part of the book, but will rather proceed immediately in the next section to Levine's defense and elaboration of "the Darwinian re-enchantment of the world."

\section{Turning Mysteries into Problems}

W. H. Mallock was, according to Levine (p. 2), one of the "most brilliant and witty antagonists" of those Victorians such as T. H. Huxley, John Tyndall, and W. K. Clifford, who "exuberantly advertised the power of science to transform the world" (p. 2). Levine (pp. 2-3) cites Mallock's melancholy observation that an increase in scientific knowledge seems to have led to a decrease in the satisfaction we are able to attain in life.

In a number of ways, whilst we have not been perceiving it, [life's] objective grandeur has been dwindling .... In the last few generations man has been curiously changing. $[\mathrm{He}]$ has become a creature looking before and after; and his native hue of resolution has been sicklied over by thought.
The early twentieth century sociologist Max Weber, according to Levine (p. 23), best formulates this sense of the dwindling objective grandeur of life. The problem is that our society has been "bureaucratically 'rationalized'," resulting in a culture which is "impersonal, routine, and mechanized" and which exists in order to sustain the "efficient and rationally organized structures upon which modern Western societies depend" (p. 23). The consequences of this for our inner life are disastrous. "Disenchantment, Weber insists, consistently affirms that without magic, without God, without teleology, enchantment is purged from the world and, with it, the world's meaning and the world's value" (p. 23). On Levine's account, Weber believes that he has recognized a dilemma. Either the world is a charmed place of mystery and wonder, or else it is explained by science. Understanding the world robs it of "transcendental spirit" and "the transcendent," "value," and "the teleological;" and it fails to evoke a "deeply emotional, visceral response" to the circumstances of human existence (p. 24).

If Weber had been able to look ahead to the present day, he would have found that the elimination of mystery and transcendence is seen as an important virtue of science by those such as the psychologist Steven Pinker, who, as Levine (p. 2) notes, claims that "our understanding of how the mind works has been 'upgraded' from a 'mystery' to a 'problem'." Levine (pp. 2-3) identifies how he believes William James might respond if he were to confront someone with views such as Pinker's.

"When we read ... proclamations of the intellect bent on showing the existential condition of absolutely everything," [James] asserts with something like contempt, "we feel-quite apart from our legitimate impatience at the somewhat ridiculous swagger of the program ... menaced and negated in the springs of our innermost life." [James] talks of "cold-blooded assimilations" that "threaten ... to undo our soul's vital secrets" and of the "assumption that spiritual value is undone if lowly origin be asserted."

Darwin, of course, is the scientist with whom we most associate the idea that we have "lowly origins." Evolutionary explanations and explanations that invoke natural selection are often intended to show that the characteristics we value as most essentially humanour appreciation of art and beauty; our capacity for love; intellect; a moral sense; religious experience and feelings of awe-are the products of an unseemly "war of all against all." Evolutionary science is often taken to be an exemplary instance of the dilemma formulated by 
Weber: Either the aspects of ourselves we most highly value have evolved by natural selection and other evolutionary processes and can be explained and made rational; or else they remain inspiring, mysterious, and wonderful. Levine seeks to show that this dichotomy is a false one. By reading Darwin's texts, by seeing how Darwin himself approached the study of nature and the wonder he felt about what he found, a third compelling alternative can be articulated: the Darwinian re-enchantment of the world.

Levine's Darwin reached his understanding of meaning and value by a hard road. Overcome by the vast suffering and the innumerable lives of both human beings and animals lost in the "struggle for existence," he violently rejected as repugnant the idea of providence, that is, the idea that there is a divine plan for the moral improvement of individuals and reward for those that are good. I describe Levine's account of Darwin's crisis in the section "The Unconsolable Darwin". As it happens, Levine believes that, although Darwin was not able to identify any way in which one could be consoled or compensated for loss and pain, he found that he could satisfy the need for wonder and a sense of belonging in his investigation of nature and its explanation by natural selection. This, the Darwinian re-enchantment of the world, is my topic in the sections "What Is Darwinian Enchantment?" and "Levine's Argument" found below.

\section{The Unconsolable Darwin}

The main line of thought in the second portion of the book has as its starting point an account of some of the origins of Darwin's dissatisfaction with the notion that there is a benevolent creator. At some point fairly early on in his study of nature, beginning as early as his Beagle voyage, Darwin found it more and more difficult to accept the idea that pain and suffering can be justified because they fit into some larger divine plan. Levine's reading imputes to Darwin a novel two-part rejection of arguments for God's existence. First, Darwin finds it incomprehensible that a benevolent deity would permit such suffering in the first place. This is the response many have to pain and suffering, which creates for them the "problem of evil." Second, Levine suggests that Darwin finds it incomprehensible that a divine creator would have created beings whose purpose in life is to suffer.

Putting together these two sources of dissatisfaction with the divine represents an interesting twist on a response often made to the argument from design. Proponents of the argument from design claim that, just as the existence of a complex, finely tuned machine such as a watch or jet engine requires a designer, so do organisms, which are just as complex and finely tuned. The human eye and hand are paradigm examples of "design" in nature. In response, some point out that there are many examples of poor design in nature: The human tailbone, tonsils and other vestigial organs, and even fundamental defects in the design of the eye. Darwin's twist on this response to the argument from design is to point out that it would be a particularly significant defect in the divine design of human beings if part of their very purpose in life were to suffer. More than just tonsillitis or the pain of falling on one's tailbone, this "design problem" threatens to induce a downwardly spiraling existential crisis in the human population. The reasoning is that either (1) the argument from design is saved, with the premise that the creator designed us to suffer as a part of some providential plan or (2) the argument from design is abandoned, because it is clear that, if there were a creator, that being made a colossal error-designing one's creatures to suffer is surely a defect in design. Darwin is drawn to (2), abandoning the argument from design.

Extending the argument, Darwin notes that humans are not the only creatures that suffer needlessly. The animal kingdom, whose citizens outnumber the human population by many orders of magnitude, is rife with pain. Many more are born than can survive; death is violently gruesome, the dead often stepped on, eaten, or simply left to rot where they lay in their final moments. Someone shocked at the amount of suffering that human beings experience would be stunned into speechless horror at the thought that a divine creator intended for this to happen, that is, for pain, suffering, and needless death to occur on such a vast scale as it does in the animal world. This could only result from ill will, a heinous mockery of creatures unfortunate enough to both have the capacity to suffer and to be helpless against a superior power. Levine (p. 162) presents an intriguing paragraph, deleted from Darwin's Autobiography by his family after his death.

That there is much suffering in the world no one disputes. Some have attempted to explain this in reference to man by imagining that it serves for his moral improvement. But the number of men in the world is as nothing compared with that of all other sentient beings, and these often suffer greatly without any moral improvement. A being so powerful and so full of knowledge as a God who could create the universe, is to our finite minds omnipotent and omniscient, and it revolts our 
understanding to suppose that his benevolence is not unbounded, for what advantage can there be in the suffering of millions of the low animals throughout almost endless time?

Darwin's thinking in this way seems to have begun early in his career, on the Beagle. Levine's (pp. 1512) view is that Darwin's description of St. Paul's rocks, seen on the Beagle voyage, is a kind of "antipoetry," which indicates that Darwin was starting to recognize the ugliness and cruelty of nature, rather than seeing it as a backdrop to providence. Levine (p. 151) quotes the following passage from Darwin concerning the origins of life on the rocks.

[I observe] a fly (Olfersia) living on the booby, and a tick which must have come here as a parasite on the birds; a small brown moth, belonging to a genus that feeds on feathers: a beetle (Quedieus) and a woodlouse from beneath the dung; and lastly numerous spiders, which I suppose prey on these small attendants and scavengers on the waterfowl.

Levine (pp. 150-1) further cites Darwin, who writes in the Voyage of the Beagle that "feather and dirtfeeding and parasitic insects and spiders [are] the first inhabitants of a newly formed oceanic island," a reality which "destroys the poetry" of "the often repeated description of the stately palm and other noble tropical plants, then birds, and lastly man, taking possession of the coral islands as soon as formed." Rather than a provident benevolence creating a peaceful and beautiful sequence of events by which a remote island is populated, ending with colonization by humans, Darwin observes ugliness, the most disgusting and unpleasant creatures arriving first.

\section{What Is Darwinian Enchantment?}

No longer able to take the idea of divine providence seriously, Darwin turned his gaze toward nature itself as a source of meaning. Rather than seek compensation for suffering by means of a divine plan, Darwin accepts that no compensation can be had, instead seeking community with those who suffer. This includes every living thing. He identifies with plants, animals, and all the other denizens of nature. Darwin personifies them, and in turn, feels affinity with them, exchanging places with them in his imagination, prepared to feel as he imagines they do. For the naturalist, this generates wonder, astonishment at what different ways of life are possible, and creates an opening in one's experience for empathy with the suffering, pain, and loss of others. This sense of wonder, amazement, and moral concern derives not from one's awareness of divine providence or a redemptive, divine meaning. Rather, it derives from the awareness that these other ways of life and the excitements, sufferings, and other "experiences" of the organisms one observes and identifies with are indeed the products of natural processes, that the ordinary ebb and flow of nature itself-by way of the usual dayto-day processes with which we are all familiar-has resulted in such complexity, in the web of relationships and dependencies characteristic of even the most simple ecosystems. A similar thought is expressed by Emerson.

The greatest delight which the fields and woods minister, is the suggestion of an occult relation between man and vegetable. I am not alone and unacknowledged. They nod to me, and I to them. The waving of the boughs in the storm, is new to me and old. It takes me be surprise, and yet is not unknown. Its effect is like that of a higher thought or a better emotion coming over me, when I deemed I was thinking justly or doing right. (Emerson 1849, 9-10)

To be clear, Levine's proposal is not that Darwin finds meaning in an alternative belief system, and in particular, Levine is not suggesting that Darwin offers an argument for such a position. My account above of Darwin's responses to arguments for the existence of God and providence describes the kinds of "gutlevel" reactions attributed to Darwin by Levine, that is, Darwin's feelings and experience of pain and its role in his sense that the world is not the product of divinity and provides no access to it - and his sense of wonder at nature. Moreover, the opportunity for enchantment Levine believes Darwin to have noticed and articulated is a particular kind of experience, a kind of moment or turning point at which someone properly attuned can experience wonder and enchantment. Furthermore, the idea is that, just as Darwin had this experience, other people-including us-can have it.

Levine elaborates concerning the nature of this experience of enchantment, drawing on the work of Jane Bennett (Bennett 2001). According to Bennett, Levine (p. 35) notes approvingly, enchantment is "a peculiar kind of mood ... I pursue a life with moments of enchantment ... rather than an enchanted life." Levine (p. 35) explains that "it might be appropriate to call the moods of enchantment 'spots of time,' moments that, while they can be relatively rare in one's life, fill it with meaning and value, and evoke memories and 
connections that themselves, become richer and fuller." He continues, quoting from Bennett.

"To be enchanted is to be struck and shaken by the extraordinary that lives amid the familiar and the everyday ... the mood I [Bennett] [am] calling enchanted," she says, "involves ... a surprising encounter," that contains "the pleasurable feeling of being disrupted or torn out of one's default sensory-psychic-intellectual disposition." Its effect is "a mood of fullness, plenitude, or liveliness, a sense of having had one's nerves or circulation or concentration powers tuned up or recharged-a shot in the arm, a fleeting return to childlike excitement about life."

Levine echoes Nietzsche's remark, made in Beyond Good and Evil (Nietzsche 2009, 62), that “A man's maturity [is] having rediscovered the seriousness that he had as a child, at play." Levine (p. 36), enlarging on Bennett's view, comments that "there we are, if unapologetically, back to Weber's 'big children'." This refers to Weber's question, "[w]ho-aside from certain big children who are indeed found in the natural sciences-still believes that the findings of astronomy, biology, physics, or chemistry could teach us anything about the meaning of the world?" (p. 32).

In conclusion to this account of Levine's understanding of Darwin's enchantment by nature, consider a useful parallel that Levine draws between Darwin and the natural theologian, Paley. Paley, well known for elaborating the argument from design, takes the wonder of nature as evidence that God exists. On the one hand, "Paley asks for wonder at the astonishing working of God;" on the other hand, "Darwin, through his metaphors, seeks to shift the wonder to the astonishing work of nature" (pp. 235-6). As well, "Darwin's anger at the failures of the world that Paley saw as designed by a beneficent Creator is manifest throughout [Darwin's work]: Would God, he said, 'ordain that the crop and tail-feathers of the pigeon should vary in order that the fancier might make his grotesque and fantail breeds?"” (p. 237).

\section{Levine's Argument}

Having presented Levine's account of Darwin's solution to the problem of disenchantment identified by Weber, I now present Levine's argument that this in fact is Darwin's solution to that problem. The central insights, Levine argues, are to be found in Darwin's prose style. On the one hand, someone might ignore Darwin's language, trying to isolate Darwin's argu- ments and claims, a practice Levine (p. 223) calls "skimming" the argument "off the top" of its presentation in Darwin's texts. Levine believes that this is possible and that it is probably necessary to do so in order to understand Darwin's biological theories. On the other hand, one might attend carefully to the language in which those arguments are formulated, in which case one would learn a great deal about Darwin's attitude toward nature. "Skimming" alone misses an important set of values Darwin holds and fundamental conclusions he reaches about how to live.

Encapsulating his interpretation of Darwin, Levine (p. 244ff) identifies a pattern in Darwin's writing that Levine sees as the central evidence that Darwin does indeed communicate the experience of enchantment to his readers. The pattern is as follows: First, Darwin expresses wonder and amazement about the phenomena he is observing, say, a part of a barnacle or the behavior of aphids or worms. This is marked in the text by exclamations to the effect that it seems highly unreasonable to believe that the phenomenon in question came about by natural means because it is so extraordinarily complex, beautiful, or because it is otherwise remarkable or strange. Second, as if to respond to his own amazement, Darwin provides just such a naturalistic explanation of the phenomenon in question. In doing so, Levine claims, Darwin does not dispel the sense of wonder that he feels, continuing to express surprise, delight, and astonishment. This is precisely contrary to Weber's expectation that explaining a phenomenon renders it insignificant, inert for the purposes of evaluating one's place in the universe or contributing to one's sense of oneself.

According to Levine, passages providing evidence of Darwin's enchantedness have two important aspects, in addition to generally proceeding according to the general strategy described above. First, Darwin often records his enchantment in passages in which fine details of some trait that is minutely small are being communicated. He offers the following example of this kind of passage (pp. 217-18).

As I am summing up the singularity of the phenomena here presented, I will allude to the marvelous assemblage being seen by me within the sac of an Ibla quadrivalvis,- - namely, an old and young male, both minute, worm-like[,] destitute of a capitulum, with a great mouth, and rudimentary thorax and limbs, attached to each other and to the hermaphrodite, which latter is utterly different in appearance and structure; secondly, the four or five, free boat-shaped larvae, with the curious 
prehensile antennae, two great compound eyes, no mouth, and six natatory legs ....

Both the general strategy I describe above and the focus on the details of a small-scale object are exemplified in this passage. Darwin starts by remarking that the objects of his study are "singular" and "marvelous;" the detailed description follows, the excitement generated by his observations remaining unabated. The passage (not quoted in full above) ends with the exclamation that although these various forms have "scarcely anything in common ... [they] all [belong] to the same species!" This is not a sober conclusion or consideration concerning the taxonomic or physiological implications of the observations such as someone whose sense of wonder had been destroyed might provide.

This is Darwin's answer to Augustine, who chastises himself for observing nature, claiming that such observation is itself a kind of sin as well as being a kind of idleness. The remedy for such sins is to attempt to wrest one's focus from nature, turning it to God. Levine's Darwin finds the observation of nature a source of value and meaning in itself: The closer the observation of nature, the richer and greater in magnitude is the sense of wonder one feels.

The second important aspect of passages in which Darwin records the experience of enchantment, according to Levine, is that they often personify ("anthropomorphize") the creatures and plants described in them. Darwin personifies the organisms he observes, describing them as though they were making decisions based on human motives and feelings. By doing so, Levine argues, Darwin identifies with his objects of study, thinking what he or someone like him would do if his place as observer were traded with his objects' places and he were among them. This establishes the identification with the organisms that is essential to Darwin's re-enchantment. One response to the amazing and wondrous complexity of nature might be to attribute those qualities to divinity. Instead, Darwin imagines his own world and way of life as continuous with those he observes, finding himself a part of nature.

As evidence of this pattern of explanation, Levine (p. 195) cites a passage from The Descent of Man concerning female choice the selection of mating partners.

With respect to female birds feeling a preference for particular males, we must bear in mind that we can judge of choice being exerted, only by placing ourselves in imagination in the same position. If an inhabitant of another planet were to behold a number of young rustics at a fair, courting and quarreling over a pretty girl, like birds at one of their places of assemblage, he would be able to infer that she had the power of choice only by observing the eagerness of the wooers to be please her, and to display their finery.

Levine (pp. 195-6) proposes that this strategy of personification is particularly well-suited for expressing enchantment because the imagined exchange of places is mutual.

The world is so thick with feeling and value as Darwin enters into the 'mind' of the female birds. It is hardly that dead, arid place that Weber tells us is the consequence of scientific explanation. Much of the Descent depends on placing ourselves imaginatively in the condition of some other being.

.

[I]n slipping into his thought experiment and creating a hypothetical encounter between a pretty country girl and competing male suitors, Darwin actually introduces [female choice] into human mating ....

Darwin's proposal that females choose mates is important, Levine argues, because there was a nearconsensus in the late nineteenth century that women did not possess the initiative or discernment necessary to identify and pursue potential partners. Darwin's thought experiment provided a means for him to imagine new possibilities for human behavior, as well as explain that of animals. Close observation is a strategy of becoming more attached to the world, of being able to understand one's needs and desires and to identify new kinds of meaning and value.

\section{Critical Questions}

I find Levine's argument convincing. I believe that Darwin did experience something like the wonder and enchantment Levine describes and that this is clearly indicated by the evidence Levine provides. As well, I believe that many other people, particularly scientists, feel a similar enchantment and sense of wonder, in just the same kinds of circumstances Darwin did. Nonetheless, there are two issues that I would like to raise in criticism of Levine's conclusion.

The first issue I would like to raise is, to whom might the Darwinian secular re-enchantment appeal? Consider two groups of people. (1) Those that are at present satisfied with the meaning and purpose of their lives, because they have religious faith or some other set of beliefs that provides them with a basis for the necessary feeling of enchantment about the world. (2) 
Those that at present are not satisfied with the meaning and purpose of their lives, having either abandoned or never having had any set of beliefs that provided the basis for the necessary feeling of enchantment about the world.

Next, consider whether members of either of these two groups would be likely to find the Darwinian re-enchantment of the world a compelling prospect. Clearly, members of group (1), those that already have some basis for feeling wonder about the world and their place in it, would not find the Darwinian re-enchantment compelling: There is no need they presently have that the re-enchantment satisfies. At some later time, should they lose their capacity for wonder, perhaps in a crisis of faith, they might begin to find the Darwinian re-enchantment attractive. Otherwise, the re-enchantment is not what William James (James 1911, 2) would call a "live option" for these people. For people in group (2), the Darwinian attitude toward nature may in fact be a "live option." Already having moved away from a supernatural (or other) source of wonder, those in this group might be moved to pursue the Darwinian re-enchantment.

Is there any kind of argument that might be used to convince those in group (1) to move away from their presently held beliefs, toward nature as the source of their enchantment? Similarly, is there any kind of argument that might draw in the uncommitted in group (2)? A central appeal of taking a Darwinian view of nature as the source of one's feelings of wonder is that the view is reasonable to believe, given the evidence we presently possess. If one is committed to the truth and to believing within the limits of reason, one must acknowledge that our relatives include many creatures we find repugnant, that we were never guaranteed any particular place in nature and that, now that we have obtained one, there is no assurance that we will keep it. The virtue of looking to a Darwinian view of nature as a source of wonder is something like Freud's suggestion that, whatever the difficulties of living within the bounds of our rationality, we must attempt, at least, do so: "[Human beings] cannot remain children for ever; they must in the end go out into 'hostile reality.' We may call this 'education to reality'" (Freud 1989, 717).

Nonetheless, as Levine (p. 257) points out, "there is no way to argue that my feeling is somehow better than your feeling." Many people are comfortable allowing that the problem of evil probably does have some solution, even if it might not be clear what it is; that science has its domain of explanatory power, and religious traditions and spirituality have another; and many people are comfortable living with contradiction and the unexplained. Levine admits that, at best, it ought to be acknowledged by everyone that "the commitment to a Darwinian and secular interpretation of such phenomena as the march of the penguins [or any other complex, adaptive behavior] is entirely compatible with those feelings of wonder and awe that have traditionally been expressed by religion, and that commitment entails the fullest possible respect and sympathy for the natural phenomena and the living beings around us" (pp. 257-8). Being able to argue that the Darwinian account of our origins and place in the universe is compatible with the experience of enchantment is not a particularly ambitious aim. What would be better would be to have an argument that everyone ought to adopt such a secular view, not just that everyone acknowledge that the view is not incoherent.

On the strength of the line of thought elaborated above, I see the appeal of the Darwinian reenchantment to be limited, even at its maximum extent. If one is already lacking the sense that the world is perfect and has come to accept that there are no consolations to be had for suffering and loss, perhaps moments of Darwinian enchantment supply a sufficient quantity of wonder for a satisfying life. For those not in this position, there is simply no reason to feel the kind of enchantment Darwin felt. For those with sufficient faith, scientific explanation does not destroy wonder, which they believe to be supernatural. Levine's book can serve, at best, as an appeal to those already inclined to look to nature but not beyond as a source of value. This in itself is an important achievement, but it might have been hoped that Levine would be able to offer a general solution to the problem of finding meaning and value in life.

The second issue I would like to raise is whether the Darwinian re-enchantment can, in fact, provide enough for someone to live a fulfilling and meaningful life. This question can be extended to enchantment more generally: Is a sense of wonder all that one needs in order to feel complete and to understand one's place in the universe? I think that it is clear that it is not. The sense of awe and wonder generated by the Darwinian re-enchantment will not satisfy the central need that belief in a non-natural source of meaning has been called upon since Plato to provide a sense of stability and continuity in a natural world of constant change. Augustine (2001, 66-7) voices this clearly.

[W] heresoever a human soul turns, it can but cling to what brings sorrow unless it turns to [the Divine], cling though it may to beautiful things outside you [the Divine] and outside itself. ... They all rise and sink; in their rising they begin to exist and grow toward their perfection, but once 
perfect, they grow old and perish; or, if not all reach old age, yet certainly all perish ....

Let my soul use these [transient] things to praise you,

O God, creator of them all,

but let it not be glued fast to them by sensual love, for [my soul] too longs to be, and loves to rest in what it loves

But in them it finds no place to rest, because they do not stand firm;

they are transient, and who can follow them with the senses of the body?

According to Levine, "material meaning is after all 'meaning,' and there is no reason (except more than two thousand years of Western history, I suppose!) to decide that meaning is only meaning when it transcends the material conditions from which it emerges" (p. 263). The appeal to a transcendent reality over "two thousand years of Western history" is not due to intellectual or spiritual inertia or prejudice-it provides the needed counterweight to the world of flux and discontinuity that is so characteristic of virtually all experience.

The natural line of response to this criticism of Darwinian re-enchantment is that, while it may be satisfying to believe that there is something not sensed or experienced directly that sustains the world through change, it is not at all clear that we are in a position to affirm the existence of this kind of thing. Science, the central tool we now have for explaining nature, generates knowledge based on experience, and its primary results apply most directly to experience. It may be difficult to face the world and at the same time deny the transcendent, but at least we will be doing so with our intellectual integrity intact, focused on improving our condition by our own efforts.

Of what use to [us] is the mirage of wide acres on the moon, whose harvest no one has yet ever seen? As honest smallholders on this earth, [we] will know how to cultivate [our] plot in such a way that supports [us]. By withdrawing ... expectations from the other world and concentrating all [our] liberated energies into ... life on earth, [we] will probably succeed in achieving a state of things in which life will become tolerable for everyone and civilization no longer oppressive to anyone. (Freud 1989, 717)

\section{Concluding Remarks}

George Levine offers a compelling view of the kind of deep attachment Darwin felt to his objects of study, broadening that view to a general account of one kind of meaning that one might find in one's own life. Levine's interpretations of both content and form of Darwin's prose are eminently convincing. Levine faces fundamental issues raised by Darwin's conception of natural selection and evolution, taking on the Socratic question, "How should one live?" in the context of evolutionary science. I hope that others are able to respond likewise, extending and exploring the novel and exciting proposals advanced in Darwin Loves You.

\section{References}

Augustine. Confessions. In: Boulding M, translator. Hyde Park: New City Press; 2001.

Bennett J. The enchantment of modern life: attachments, crossings, ethics. Princeton: Princeton University Press; 2001.

Emerson R. Nature. In: Nature: addresses, and lectures. Boston: James Monroe; 1849.

Freud S. The future of an illusion. In: The Freud reader. Gay P, editor. New York: W. W. Norton; 1989.

James W. The will to believe. In: The will to believe and other essays in populalar philosophy. New York: Longmans, Green, and Co.; 1911.

Nietzsche F. Beyond good and evil. In: Faber M, translator. New York: Oxford University Press; 2009. 